\title{
Contrasting survival and physiological responses of sub-Arctic plant types to extreme winter warming and nitrogen
}

\author{
Stef Bokhorst ${ }^{1,2}$ (1) Laura Jaakola $^{3,4} \cdot$ Katja Karppinen $^{3,5} \cdot$ Guro K. Edvinsen $^{6} \cdot$ Hanne K. Mæhre $^{6} \cdot$ Jarle W. Bjerke $^{1}$
}

Received: 13 July 2017 / Accepted: 2 October 2017 / Published online: 21 November 2017

(c) The Author(s) 2017. This article is an open access publication

\begin{abstract}
Main conclusion Evergreen plants are more vulnerable than grasses and birch to snow and temperature variability in the sub-Arctic.
\end{abstract}

Most Arctic climate impact studies focus on single factors, such as summer warming, while ecosystems are exposed to changes in all seasons. Through a combination of field and laboratory manipulations, we compared physiological and growth responses of dominant sub-Arctic plant types to midwinter warming events $\left(6^{\circ} \mathrm{C}\right.$ for 7 days $)$ in combination with freezing, simulated snow thaw and nitrogen additions. We aimed to identify if different plant types showed consistent physiological, cellular, growth and mortality responses to these abiotic stressors. Evergreen dwarf shrubs and tree seedlings showed higher mortality (40-100\%) following extreme winter warming events than Betula pubescens tree seedlings and grasses (0-27\%). All species had growth reductions following exposure to $-20^{\circ} \mathrm{C}$, but not all species suffered from $-10{ }^{\circ} \mathrm{C}$ irrespective of other treatments. Winter warming followed by $-20^{\circ} \mathrm{C}$ resulted in the greatest mortality and was strongest among evergreen plants. Snow removal reduced the biomass for most species and this was exacerbated by subsequent freezing. Nitrogen increased the growth of B. pubescens and grasses, but not the evergreens, and interaction effects with the warming, freezing and snow treatments were minor and few. Physiological activity during the winter warming and freezing treatments was inconsistent with growth and mortality rates across the plants types. However, changes in the membrane fatty acids were associated with reduced mortality of grasses. Sub-Arctic plant communities may become dominated by grasses and deciduous plants if winter snowpack diminishes and plants are exposed to greater temperature variability in the near future.

Keywords C-repeat binding factor $\cdot$ Fatty acids $\cdot$ Frost $\cdot$ Grass $\cdot$ Multiple stresses $\cdot$ Shrub $\cdot$ Snow

Electronic supplementary material The online version of this article (doi:10.1007/s00425-017-2813-6) contains supplementary material, which is available to authorized users.

Stef Bokhorst

s.f.bokhorst@vu.nl

1 Norwegian Institute for Nature Research (NINA), FRAM - High North Research Centre for Climate and the Environment, Langnes, PO Box 6606, 9296 Troms $\varnothing$, Norway

2 Department of Ecological Science, VU University Amsterdam, De Boelelaan 1085, 1081 HV Amsterdam, The Netherlands

3 Climate Laboratory Holt, Department of Arctic and Marine Biology, UIT The Arctic University of Norway,

9037 Tromsø, Norway

\author{
Abbreviations \\ C Control \\ CBF C-repeat binding factor \\ $\mathrm{N} \quad$ Nitrogen \\ S Snow
}

4 Norwegian Institute of Bioeconomy Research (NIBIO), PO Box 115, 1431 Ås, Norway

5 Genetics and Physiology Unit, University of Oulu, PO Box 3000, FI-90014 Oulu, Finland

6 Faculty of Biosciences, Fisheries and Economics, Norwegian College of Fishery Science, UIT The Arctic University of Norway, 9037 Tromsø, Norway 
TC Treatment control

WW Extreme winter warming

\section{Introduction}

The Arctic is experiencing more extreme weather events due to climate change, causing high mortality rates among species when events surpass survival thresholds (Post et al. 2009; Liston and Hiemstra 2011). Especially, winter is expected to experience more extreme events such as rain on snow, unseasonal warm periods, ground ice formation and loss of snow cover (Post et al. 2009; Vikhamar-Schuler et al. 2016). Abrupt changes in winter snow cover and depth following midwinter thaw events (e.g., from -20 to $+5{ }^{\circ} \mathrm{C}$ in $24 \mathrm{~h}$ ) affect plant survival as snow insulates against temperature extremes (Bokhorst et al. 2016). In addition, loss of snow cover during a midwinter melt can induce plant physiological activity, while the plants are generally dormant (Ögren 1996; Schaberg et al. 1996; Bokhorst et al. 2010). Evergreen plants seem to be more susceptible than deciduous plants and grasses to such events, but the cause of this is unclear (Bokhorst et al. 2009, 2011, 2015). Evergreen plants have more 'alive' green tissue aboveground and can potentially respond more strongly to abiotic cues making them more susceptible to damage, whereas deciduous plants have dormant buds which may take longer to develop and respond to midwinter warming events. Plant mortality can result from loss of frost hardiness due to physiological activity induced by the winter warming event (Strimbeck et al. 1995; Beck et al. 2004; Buchner and Neuner 2011; Pagter and Arora 2013) or increased freeze-thaw cycles and lower freezing temperature from the reduced snow cover (Lund and Livingston 1999). In addition, frost drought and leaf cuticle abrasion may result in tissue damage (Hadley and Smith 1986, 1989; Neuner et al. 1999). Identifying the drivers behind plant vulnerability allows for a better understanding of sub-Arctic vegetation changes, as the predictions of winter climate and snow conditions vary across circumpolar regions (Liston and Hiemstra 2011).

Basic physiological processes, such as respiration and the activity of the photosynthetic apparatus, slow down or stop altogether in response to colder winter temperature as a protection against freezing damage (Inouye 2000). This cold hardening slowly builds up during the autumn-winter transition under genetic control (Hughes and Dunn 1996; Thomashow 1999). The composition of fatty acids in the cell membrane plays an important role in the protective actions against frost damage (Steponkus 1984; Hughes and Dunn 1996), and many plants increase the unsaturated and longer fatty acid chains to limit membrane denaturation by freeze dehydration (Uemura et al. 1995; Uemura and Steponkus 1999; Dalmannsdóttir et al. 2001; Strimbeck et al. 2015).
However, it is unclear if sub-Arctic plants can re-initiate these cold hardening processes following an abrupt midwinter warming event. Furthermore, extreme winter warming events occur against a background of gradually increasing temperature and anthropogenic disturbances such as nitrogen deposition.

Atmospheric nitrogen $(\mathrm{N})$ deposition is a global threat to biodiversity and ecosystem function. Critically, even low-dose $\mathrm{N}$ deposition $\left(5-10 \mathrm{~kg} \mathrm{~N} \mathrm{ha}^{-1}\right.$ year $^{-1}$ ) may lead to eutrophication of the ecosystem and affect plant communities (Phoenix et al. 2012; Choudhary et al. 2016). In addition, many plants show changes in cell and physiological characteristics that are associated with drought and frost susceptibility when exposed to $\mathrm{N}$ deposition (Macgillivray et al. 1995; Carroll et al. 1999; Schaberg et al. 2002). As such, increased $\mathrm{N}$ inputs from agricultural practices or biomass burning reaching high latitudes (Forsius et al. 2010; Karlsson et al. 2013) could make sub-Arctic plants more vulnerable to the temperature variability of extreme winter warming events (Power et al. 1998).

To address these issues, we initiated a common garden experiment where the physiology (respiration rates, changes in fatty acid composition and gene expression of frostresistant genes) of dominant sub-Arctic plant types (grasses, dwarf shrubs and trees) was monitored during simulations of extreme winter warming events in combination with $\mathrm{N}$ additions in sub-Arctic Norway. We expected that (1) evergreen plants would show larger growth reductions and mortality rates as compared to deciduous plants and grasses in response to extreme winter warming events because evergreens have more green tissue underneath the snow; (2) evergreen mortality would result from physiological activity in response to the winter warming period combined with a lack of physiological adaptations (changing fatty acid composition and gene expression); (3) freezing $\left(-10\right.$ and $-20{ }^{\circ} \mathrm{C}$ ) following the extreme winter warming events will result in higher mortality rates irrespective of plant growth form, and that the loss of snow cover will exacerbate these effects; and (4) $\mathrm{N}$ addition will induce higher mortality when combined with extreme winter warming events. Identifying the strategies of various plant species and groups, such as evergreen dwarf shrubs, grasses and deciduous and evergreen trees, will provide predictive tools for modeling future sub-Arctic vegetation changes and carbon and nutrient cycling rates (Cornelissen et al. 2007; De Deyn et al. 2008). 


\section{Materials and methods}

\section{Extreme winter warming manipulation and simulation of nitrogen deposition}

To determine the vulnerability of sub-Arctic plants to winter temperature variability, plants were collected from the field or grown from seeds during spring 2013 (see details below) and divided across three temperature treatments in the experimental garden at Holt (Troms $\varnothing$, Norway, $69^{\circ} 40^{\prime} \mathrm{N}$, $\left.18^{\circ} 56^{\prime} \mathrm{E}\right)$. For the simulation of the extreme winter warming events and freezing, we removed plants from the experimental garden during January 2014 and exposed them to various temperature regimes under controlled conditions in climate chambers after which the plants were returned to the experimental garden for the remainder of winter (Fig. S1). The ambient climate conditions of the Troms $\emptyset$ area during the winter months of 2014 are presented in Table S1. A group of potted plants ( $n=40$ replicate potted plants per species) was left in the experimental garden as a control, while snow was removed from the remainder of the plants and divided across two dark climate chambers at 0.5 and $6.0^{\circ} \mathrm{C}$ for a week $(n=120$ replicate potted plants per species for each temperature). The $0.5{ }^{\circ} \mathrm{C}$ temperature was considered an ambient 'treatment control' (TC) of the subnivean temperature, while the $6.0^{\circ} \mathrm{C}$ temperature represents the 'extreme winter warming' (WW) (Bokhorst et al. 2009). To quantify the impact of freezing on the survival and growth of the study plants following 3 days at TC or WW, we split the 120 replicate pots per species across three groups: one with exposure to $-10^{\circ} \mathrm{C}$, another with exposure to $-20^{\circ} \mathrm{C}$, and the third remained at the respective TC $\left(0.5^{\circ} \mathrm{C}\right)$ or WW $\left(6.0^{\circ} \mathrm{C}\right)(n=40$ per species for each treatment). The exposure of plants to -10 or $-20{ }^{\circ} \mathrm{C}$ was done in dark climate chambers. The temperature in the climate chambers was gradually lowered from 0 to $-10{ }^{\circ} \mathrm{C}$ at $1 \mathrm{~K} \mathrm{~h}^{-1}$ and at $2 \mathrm{~K} \mathrm{~h}^{-1}$ to $-20^{\circ} \mathrm{C}$. After 2 days at the respective freezing, the plants were returned to their starting temperature $(0.5$ or $6.0^{\circ} \mathrm{C}$ ) for two more days. Following these treatments, all plants were returned to the field but only half of each treatment received a new snow cover; meaning that for every temperature treatment combination there was one insulated by snow $(+S)$, while the other was left exposed to variable ambient freezing conditions for the remainder of winter due to the lack of snow cover $(-\mathrm{S})$. As an example of the full experimental design for the $0.5^{\circ} \mathrm{C}$ treatments (TC) we now have: 'TC $+\mathrm{S}$ ', 'TC $-\mathrm{S}$ ', 'TC exposed to $-10{ }^{\circ} \mathrm{C}+\mathrm{S}$ ', 'TC exposed to $-10{ }^{\circ} \mathrm{C}-\mathrm{S}$ ', 'TC exposed $-20^{\circ} \mathrm{C}+\mathrm{S}$ ' and 'TC exposed $-20^{\circ} \mathrm{C}-\mathrm{S}^{\prime}$. The plants from the $+\mathrm{S}$ and $-\mathrm{S}$ pairs of each temperature treatment (e.g., 'TC $+\mathrm{S}$ ' and 'TC $-\mathrm{S}$ ') were placed in two adjacent rectangles $(120 \mathrm{~cm} \times 240 \mathrm{~cm})$
$1 \mathrm{~m}$ apart with the potted plants in trays $(60 \mathrm{~cm} \times 30 \mathrm{~cm})$ randomly placed within each rectangle.

To avoid crushing the plants with the manual build of a new snowpack, the plants were first covered with $20 \mathrm{~cm}$ of fine lightweight hoarfrost, collected from the surrounding snow surfaces, after which the snow level was brought back up to $80 \mathrm{~cm}$ with shoveled snow from the surrounding area. Snow was also removed from half of the plants of the control treatment (already split into two groups during summer 2013) to quantify the impact of snow removal on plant survival and growth when not exposed to extreme winter warming events (' $\mathrm{C}+\mathrm{S}$ ' and ' $\mathrm{C}-\mathrm{S}$ '). After the treatments, the plants were left untouched for the remainder of winter and spring until collected for harvesting during summer (mid-July) 2014 . Soil surface temperature $(0-1 \mathrm{~cm}$ depth) was measured at hourly intervals from autumn (2013) to spring (2014) by a temperature logger (I-Button, Maxim integrated, San Jose, CA, USA) in one potted plant for each treatment. From these data, we quantified the minimum temperature, the number of freezing events (freeze-thaw cycles) and spring thaw date.

To quantify the impact of nitrogen $(\mathrm{N})$ addition in combination with extreme winter warming effects, half of each experimental treatment received additional $\mathrm{N}$ ( $5 \mathrm{~kg} \mathrm{~N} \mathrm{~m}^{-2}$ year $^{-1}$ ) during the growing season (2013) before the extreme winter warming events. $\mathrm{N}$ was applied by watering the plants twice during the growing season (30 July and 15 August). The $\mathrm{N}$ treatments received in total $2 \mathrm{~L}$ of an ammonium nitrate $\left(\mathrm{NH}_{4}-\mathrm{NO}_{3}\right)$ solution, while the non-nitrogen plants received an equal amount of tap water. The total amount of water added was less than $1 \%$ of the mean annual precipitation falling in Troms $\varnothing(1031 \mathrm{~mm})$. There were ten replicate plants per species for each temperature-nitrogen treatment.

\section{Study species}

As we expected to find contrasting vulnerability between plant species and plant growth forms to extreme winter warming events (Bokhorst et al. 2015), we aimed to compare the differences between dominant sub-Arctic plant species and plant functional types. As representatives of evergreen plants, we used the dwarf shrubs Empetrum nigrum and Vaccinium vitis-idaea, tree seedlings of Picea abies and Pinus sylvestris (grown from seeds during the summer preceding the winter treatments) and the rosette plant Pyrola grandiflora ssp. norvegica. We used seedlings of the deciduous tree Betula pubescens and the three grasses Poa alpina, Phleum alpinum and Festuca rubra ssp. richardsonii which retain some overwintering leaves (all grown from seeds during the summer preceding the winter treatments). The grasses are included in the deciduous group in this study as their main green biomass has to regrow in spring. P. alpina, $P$. 
alpinum and $F$. rubra are a dominant component of many sub-Arctic ecosystems and their overwintering leaves allow for physiological measurements during winter which would be limited if all leaves senesce during autumn. From here on, genus names will be used to identify the different species. The grass and tree species were all grown from seeds in greenhouses at the climate laboratory Holt in Troms $\varnothing$ and transferred to individual pots $(5 \mathrm{~cm} \times 5 \mathrm{~cm} \times 5 \mathrm{~cm})$ with potting soil (spring 2013). A total of 1680 potted individuals ( $n=280$ for each tree and grass species) were used in the experiment with 20 individuals (pots) per species used as replicates for each treatment of which half received additional $\mathrm{N}(n=10$ with additional $\mathrm{N}$ and $n=10$ without $\mathrm{N})$.

As the dwarf shrubs are very slow growing, we collected complete soil-vegetation mats $(60 \mathrm{~cm} \times 30 \mathrm{~cm}$ and approximately 7-9 cm soil) dominated by Empetrum and Vaccinium from a Scots pine forest in the interior of Troms County $\left(69^{\circ} 23^{\prime} \mathrm{N}, 20^{\circ} 16^{\prime} \mathrm{E}\right)$, with similar elevation and exposure to the experimental garden during April 2013. The soil-vegetation mats were kept in plastic trays $(60 \mathrm{~cm} \times 30 \mathrm{~cm})$ filled with clean river sand to allow root growth. Pyrola individuals (including roots and peat) were collected by hand from a fen in the same area and planted within the soil-vegetation mats dominated by Empetrum and Vaccinium. Due to the space limitations in the climate chambers for the winter treatments, we used ten replicate trays with Empetrum and Vaccinium and Pyrola for each treatment ( $n=5$ with additional $\mathrm{N}$ and $n=5$ without $\mathrm{N}$ ).

\section{Plant survival/mortality}

During mid-July 2014, we calculated the relative population mortality rates for each species assuming that necrosis of the aboveground plant parts (complete browning) was indicative of complete dieback of plant individuals. As we lack individual plants for the mat-forming dwarf shrubs Empetrum and Vaccinium, we calculated $\%$ mortality from the relative mass of dead shoots compared to total standing aboveground biomass (including both alive and dead shoots based on oven dry mass) in each soil-vegetation mat during mid-July. For the grasses and trees, we quantified individual plant total biomass (shoots and roots) after drying $\left(70{ }^{\circ} \mathrm{C}\right.$ for $48 \mathrm{~h}$ ).

\section{Winter physiological activity}

During the winter manipulations, we collected the leaf tips of the green overwintering tissue of the grasses, intact leaves of Vaccinium and Picea and shoot tips of Empetrum, except from Betula and Pinus as leaves were not available for Betula and there were not enough leaves of Pinus. These samples were analyzed to quantify the winter physiological activity of the plants (respiration rates and potential activity of PSII; Fv/Fm), potential cell membrane damage through electrolyte leakage, fatty acid composition of cell membranes and expression of the $C$-repeat binding factor $(C B F)$ gene involved in frost resistance. Samples were collected after 3 days at the respective acclimation temperature (TC and $\mathrm{WW}$ ) and $24 \mathrm{~h}$ following the freezing treatments.

Leaf respiration was measured in complete darkness using a leaf gas exchange system (GFS-3000, Walz GmbH, Effeltrich, Germany) with the measuring head set at 0.5 or $6{ }^{\circ} \mathrm{C}$, depending on the acclimation temperature (TC or WW) of the plants, and 7000 ppm $\mathrm{H}_{2} \mathrm{O}$, with a 380-ppm base level of $\mathrm{CO}_{2}$. We used Walz' cuvette 3010-V80, which is specifically designed for small, loose samples. For small individual leaves or tissue, we turned the cuvette upside down, so that the leaves were on top of the ventilated lid and thereby closer to the light source and emitting a stronger fluorescence signal. Leaf samples were collected from individual plants after 3 days at their acclimation temperature $\left(0.5\right.$ or $\left.6{ }^{\circ} \mathrm{C}\right)$ and following freezing. Tissue samples were measured within 5 min of collection to obtain a representative estimate of physiological activity between treatments. We used the mean respiration rates of nine measurements taken at $15 \mathrm{~s}$ intervals for each sample $(n=5$ per species for each treatment). Fv/Fm was quantified for each leaf/tissue sample at the end of the gas exchange measurements. As the samples were not exposed to any light sources during sampling, we assume that the leaves were properly dark adapted for fluorescence measurements.

The electrolyte leakage method was used to assess the potential damage of cell membranes due to freezing (Caporn et al. 1994). Intact leaves, although grass leaves were cut, were sampled from each species before and after freezing ( $n=10$ per species for each treatment). Samples were placed in a plastic tube with $30 \mathrm{~mL}$ distilled water, shaken briefly and stored at room temperature for $6 \mathrm{~h}$. The conductivity of the solution was measured with a conductivity meter (HI 9835; Hanna Instruments, Leighton Buzzard, UK) after this period to quantify the initial electrolyte loss, although some authors use longer sample storage periods to increase electrolyte leakage values (Murray et al. 1989; Kathke and Bruelheide 2011). The sealed tubes with plant samples were then autoclaved $\left(120{ }^{\circ} \mathrm{C}\right.$ for $\left.4 \mathrm{~h}\right)$ to completely destroy the integrity of the cell membranes and release all electrolytes to acquire the maximum conductivity of each sample. The ratio of the initial to the maximum conductivity was calculated and compared across the treatments with high values indicative of a higher proportion of cell membrane damage.

To quantify changes in the fatty acid composition of the membranes as a result of the warming and freezing treatments, we collected leaf samples $(n=5)$, while plants had been acclimated to $\mathrm{TC}\left(0.5^{\circ} \mathrm{C}\right)$ or $\mathrm{WW}\left(6.0^{\circ} \mathrm{C}\right)$ for 3 days and following the freezing $\left(-10\right.$ and $\left.-20^{\circ} \mathrm{C}\right)$ treatments. All samples were immediately frozen at $-20{ }^{\circ} \mathrm{C}$, freeze dried, ground and analyzed for fatty acids following the 
direct methylation procedure (Browse et al. 1986). Samples of 5-20 mg were dissolved in $1 \mathrm{~mL}$ methanolic hydrochloric acid ( $\mathrm{HCl})(1 \mathrm{M})$ and an internal standard (heptadecanoic acid, C17:0) was added to a glass tube. The solution was heated to $80-100{ }^{\circ} \mathrm{C}$ for $1 \mathrm{~h}$, and after cooling $0.4 \mathrm{~mL}$ hexane and $1 \mathrm{~mL}$ of $0.9 \%$ sodium chloride $(\mathrm{NaCl})$ were added to each sample. The fatty acid methyl esters (FAMES) were extracted into the hexane phase by vigorous shaking on a benchtop shaker $(10 \mathrm{~s})$. The tubes were centrifuged for $10 \mathrm{~min}$ (at $212 \mathrm{~g}$ ) to separate the phases completely, and a sample was then taken directly from the hexane phase. Samples were stored at $-20{ }^{\circ} \mathrm{C}$ until gas chromatography (GC) analyses, according to Mæhre et al. (2013). The instrument used was an Agilent $6890 \mathrm{~N}$ equipped with a flame ionization detector (FID) (Agilent Technologies Inc., Santa Clara, CA, USA) and a CP7419 capillary column $(50 \mathrm{~m} \times 250 \mu \mathrm{m} \times 0.25 \mu \mathrm{m}$ nominal, Varian Inc., Middelburg, the Netherlands). The fatty acids were identified by comparing against the commercial fatty acid standards PUFA 1, 2 and 3 (Sigma-Aldrich, St. Louis, MO, USA) and the GLC standards 80, 411 and 412 (NuChec Prep. Inc., Elysian, MN, USA). The amount of each fatty acid was calculated by comparing the peak area with the known amount of an internal standard (C17:0).

To quantify the expression of the frost-resistant $C B F$ gene, plant tissues were sampled before, during and after the freezing treatments $\left(-10\right.$ and $\left.-20^{\circ} \mathrm{C}\right)$. The samples were immediately placed at $-80{ }^{\circ} \mathrm{C}$ until used for RNA extraction. Total RNA was isolated from the tissues according to Jaakola et al. (2001) with the exception that the phenol-chloroform extraction was substituted with the RNA purification protocol of E.Z.N.A. Total RNA Kit I (Omega Bio-Tek, Norcross, GA, USA) after treatment with DNase I (Sigma-Aldrich). The cDNA was synthesized from total RNA using the SuperScript VILO cDNA Synthesis Kit (Invitrogen, Carlsbad, CA, USA) according to the manufacturer's instructions. Sequences of the Empetrum $C B F$ gene were isolated by PCR with degenerate oligonucleotide primers 5'-GATGGCTGCTAGGGCTCAYGAYGTNGC-3' (forward) and 5'-GGAGGCAGCAGCATTCCYTCNGCCAT-3' (reverse) that were designed using the CODEHOP software (Rose et al. 2003) based on conserved regions found in previously isolated dicot $C B F$ proteins. Empetrum DNA extracted with E.Z.N.A. HP Plant DNA Mini Kit (Omega Bio-Tek) was utilized for amplification of $C B F$ fragments by using Phusion DNA polymerase (ThermoFisher Scientific Inc., Waltham, MA, USA) under standard PCR conditions with annealing temperature of $54{ }^{\circ} \mathrm{C}$. The amplified PCR product was gel-purified with E.Z.N.A. Gel Extraction Kit (Omega Bio-Tek) and ligated into a pJET cloning vector using CloneJET PCR Cloning Kit (ThermoFisher). Sequencing was performed using a BigDye Terminator Cycle Sequencing Kit (Applied Biosystems, Foster City, CA, USA) and sequenced at the Sanger facility in Troms $\emptyset$. The nucleotide sequence of Empetrum CBF is deposited in GenBank under Accession number KX618729. The quantitative reverse transcription PCR (qRT-PCR) analysis to determine transcript abundance of Empetrum CBF and Vaccinium CBF (GenBank Accession no. JN866912; Oakenfull et al. 2013) was performed with a MiniOpticon instrument (Bio-Rad, Hercules, CA, USA) using SsoFast ${ }^{\mathrm{TM}}$ EvaGreen Supermix (Bio-Rad). The qRT-PCR conditions were an initial incubation at $95^{\circ} \mathrm{C}$ for $10 \mathrm{~min}$ followed by 45 cycles of $95^{\circ} \mathrm{C}$ for $10 \mathrm{~s}, 60^{\circ} \mathrm{C}$ for $20 \mathrm{~s}$, and $72^{\circ} \mathrm{C}$ for $10 \mathrm{~s}$. For the relative quantification of PCR products, $18 \mathrm{~S}$ ribosomal RNA was used as a reference gene. The gene-specific primer sequences used for the qRT-PCR analysis are shown in Supplementary Table S2. The results were calculated using the calibrator-normalized PCR efficiency-corrected method using the CFX Manager software 2.0 (Bio-Rad). The amplification of only one product in qRT-PCR was confirmed by a melting curve analysis. Quantifying the expression of $C B F$ genes was only successful for Empetrum and Vaccinium. Thus, we were unable to do the planned comparison of evergreen and deciduous plant responses.

\section{Statistical analyses}

To compare the impact of treatments (C, TC and WW), extremes $\left(-10\right.$ and $\left.-20^{\circ} \mathrm{C}\right), \mathrm{N}$ addition and snow removal on plant survival, we used a Chi-square test with the following null hypothesis: 'There is no difference in the number of dead and alive plants between the treatment comparisons'. We used a factorial ANOVA to compare the impact of winter warming (TC: $0.5^{\circ} \mathrm{C}$ vs WW: $6.0^{\circ} \mathrm{C}$ ), temperature extremes $\left(0.5,6.0,-10\right.$ and $\left.-20^{\circ} \mathrm{C}\right)$ and $\mathrm{N}$ addition $(0$ vs. $5 \mathrm{~kg} \mathrm{~m}^{-2}$ year $^{-1}$ ) on plant biomass, physiological variables and the concentration of fatty acids. As plant biomass was quantified during the following growing season, we also included the impact of snow removal in the factorial ANOVA. To summarize the large number of fatty acids into fewer variables, we performed a principal component analysis (PCA) on the proportional data for each of the identified fatty acids. We compared the impact of winter warming, temperature extremes and $\mathrm{N}$ addition on the scores of PC1 and PC2. There were few significant interaction terms, and we therefore only show the main effect responses in the table and figures. Where relevant, the interaction terms are mentioned in "Results". In all cases, homogeneity of variance was tested with a Levene's test of equality, and log transformation was applied when necessary. All statistical analyses were carried out using R 3.3.0 (R Core Team 2015). 


\section{Results}

\section{Impact of temperature treatments and snow removal on the plant environment}

Snow removal lowered the minimum soil surface temperature in the control plots to $-5{ }^{\circ} \mathrm{C}$ during the remainder of winter, while temperature did not fall below $-1{ }^{\circ} \mathrm{C}$ when the snow layer was intact (Fig. 1a). Minimum temperature was lower $\left(-12{ }^{\circ} \mathrm{C}\right)$ in some of the other snow removal treatments due to a few days with colder frost during which both control plots were still covered by snow (Fig. 1b-d). Minimum soil temperature measured in the $-10{ }^{\circ} \mathrm{C}$ treatment was $-7{ }^{\circ} \mathrm{C}$ (Fig. 1c) and $-15^{\circ} \mathrm{C}$ in the $-20^{\circ} \mathrm{C}$ treatment (Fig. 1d). There was no difference in the number of freeze-thaw cycles between snow-covered $(4 \pm 1)$ and snow removal plots $(5 \pm 1)$. There was no significant difference between treatments in the date of spring thaw, i.e., the date preceded by three consecutive days with daily mean temperature above $0{ }^{\circ} \mathrm{C}$ (day of year 128).

\section{Impact of winter temperature variability on population mortality}

Betula and Festuca plants survived the winter treatments (Fig. 2a). Poa mortality was limited to WW (27\%): specifically, $100 \%$ mortality following the combination of: WW, $-20{ }^{\circ} \mathrm{C},+\mathrm{N}$ and $-\mathrm{S}$ (Fig. 2a). Phleum survived in the control plots, but there was $25 \%$ mortality in TC and WW. In addition, freezing to -10 and $-20{ }^{\circ} \mathrm{C}$ resulted in 35 and $83 \%$ mortality, respectively (Fig. $2 b$ ). Snow removal resulted in 51\% Phleum mortality, compared to $30 \%$ with snow cover, but WW and freezing increased mortality to $80 \%\left(-10{ }^{\circ} \mathrm{C}\right)$ and $100 \%\left(-20{ }^{\circ} \mathrm{C}\right)$. Overall, there was no effect of $\mathrm{N}$ on mortality for any of the deciduous species (birch and grasses).

Most of the evergreen plants sustained considerable mortality following the WW and freezing, although there were differences between species. Pyrola mortality was $30 \%$ in the control, TC and WW, while freezing to -10 and $-20{ }^{\circ} \mathrm{C}$ increased mortality to 43 and $88 \%$, respectively (Fig. 2b). There was no effect of $\mathrm{N}$ or $-\mathrm{S}$ on Pyrola mortality. Picea mortality was 0,43 and $100 \%$ in C, TC and WW, respectively, and 68 and $89 \%$ following the -10 and $-20{ }^{\circ} \mathrm{C}$ freezing (Fig. 2c). There were no consistent effects of $\mathrm{N}$ or $-\mathrm{S}$ on mortality. $98 \%$ of Pinus seedlings died in WW, 53\% died in TC, while 10\% died in the control. Pinus seedlings did not survive the $-20{ }^{\circ} \mathrm{C}$ and only $22 \%$ survived the $-10^{\circ} \mathrm{C}$ freezing (Fig. 2c). Pinus exposed to ' $\mathrm{TC}-10{ }^{\circ} \mathrm{C}+\mathrm{N}$ ' did not survive, while those without $\mathrm{N}$ did. Mortality, based on biomass, of Empetrum and Vaccinium did not differ between TC, WW and $-10{ }^{\circ} \mathrm{C}$, but was highest after $-20^{\circ} \mathrm{C}$ (Fig. 2d). There was no main effect of $-\mathrm{S}$ on Empetrum mortality, except following the most extreme event (WW $-20^{\circ} \mathrm{C}$ ) when mortality was $67 \%$ with snow and $97 \%$ without snow. Snow removal increased the
Fig. 1 Daily mean soil surface temperature during and following the extreme winter warming and freezing experiments. a Soil surface temperature in control plots with and without snow $(-\mathrm{S})$. b Temperature in the 'Treatment Control' $\left(0.5^{\circ} \mathrm{C}\right)$ and 'WW' $\left(6^{\circ} \mathrm{C}\right)$ treatment with and without snow. c Soil surface temperature of the potted plants during and following exposure to $-10{ }^{\circ} \mathrm{C}$ (for TC and WW) with and without snow. $\mathbf{d}$ Soil surface temperature of the potted plants during and following exposure to $-20{ }^{\circ} \mathrm{C}$ (for TC and $\mathrm{WW}$ ) with and without snow. Days of the year (DOY) from 1 January until 1 May are shown on the horizontal axes

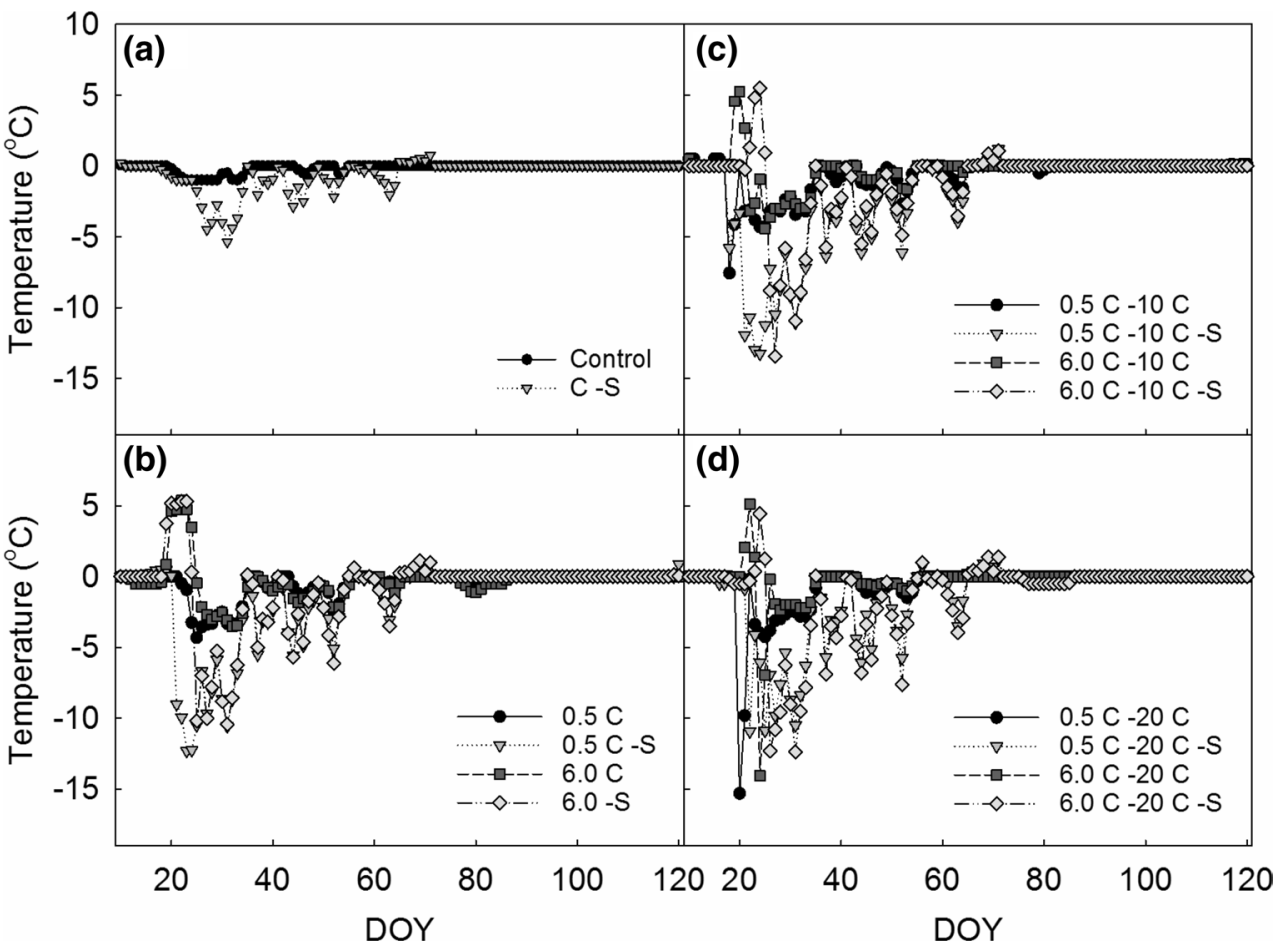


Fig. 2 Survival of sub-Arctic plants following simulations of extreme short winter warming events. The treatments included a true control $(\mathrm{C})$, a treatment control (TC at $0.5^{\circ} \mathrm{C}$ ), a winter warming treatment (WW at $6{ }^{\circ} \mathrm{C}$ ) and freezing exposure to -10 and $-20^{\circ} \mathrm{C}$. a All Betula (black) and Festuca (gray) survived, while $73 \%$ of Poa (white) plants survived when exposed to winter warming. b Survival of the grass Phleum and rosette plant Pyrola. c Survival of evergreen tree seedlings (Pinus and Picea). d Survival of evergreen dwarf shrubs (Empetrum and Vaccinium)

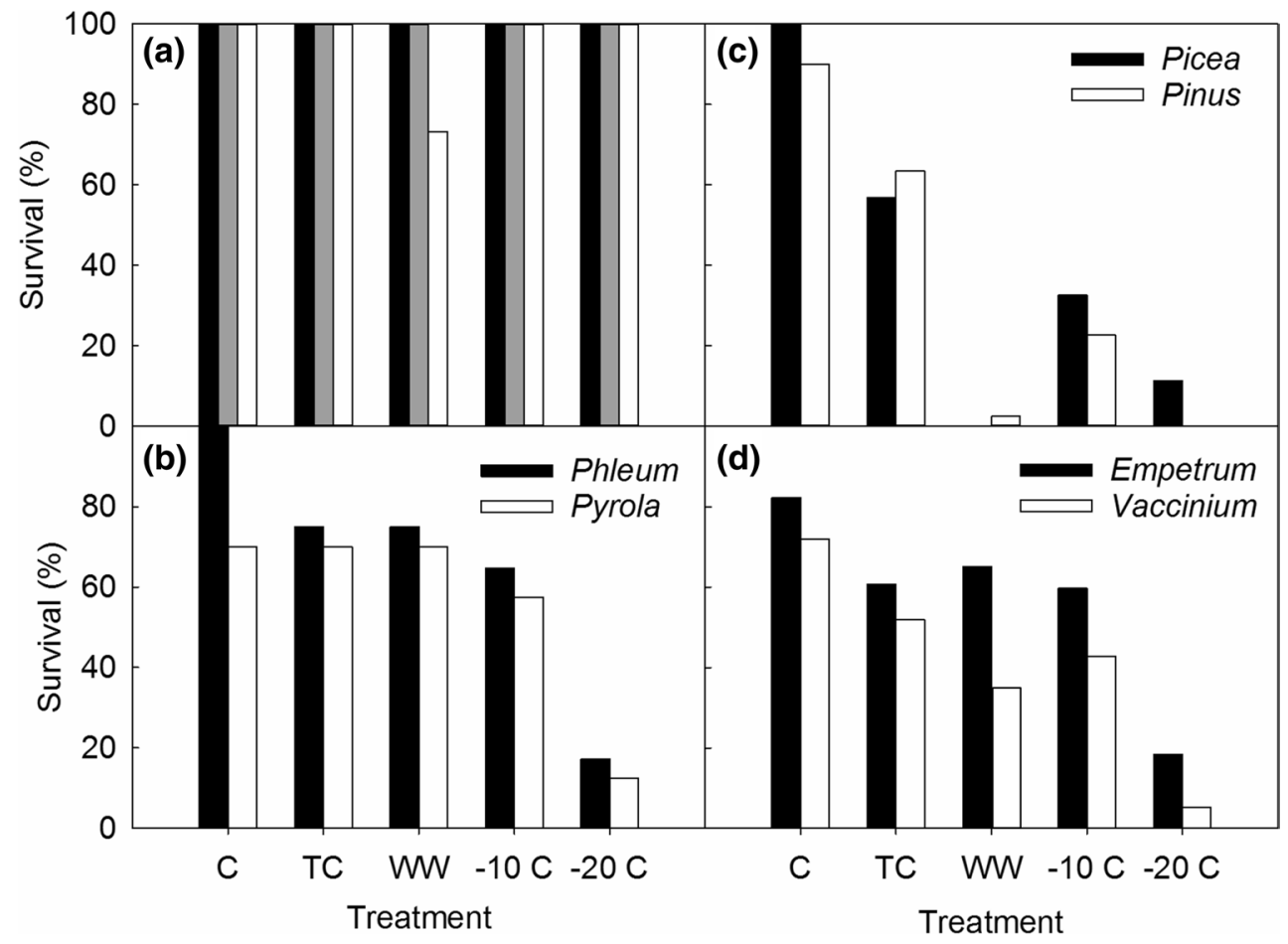

mortality of Vaccinium to $67 \%$ compared to $60 \%$ mortality when plants were covered by snow.

\section{Impact of extreme events on subsequent biomass production of surviving plants}

All plants, except Festuca and Picea, experienced decreased biomass following the transferral from the subnivean environment to the climate chambers compared to the control plots that were left undisturbed in their subnivean environment the entire winter (Fig. 3). Betula, Festuca and Poa showed reduced biomass following $-20^{\circ} \mathrm{C}$, while no biomass differences were found between $\mathrm{TC}, \mathrm{WW}$ and $-10{ }^{\circ} \mathrm{C}$ (Fig. 3a-c). The biomass of Festuca and Poa was 43 and $50 \%$ lower in ' $\mathrm{WW}-20^{\circ} \mathrm{C}$ ' than in ' $\mathrm{TC}-20{ }^{\circ} \mathrm{C}$ '. Phleum showed an intermediate response in that plants exposed to $-10{ }^{\circ} \mathrm{C}$ and had lower biomass compared to TC and WW, while $-20{ }^{\circ} \mathrm{C}$ was even lower (Fig. 3d). The biomass of the evergreens Pyrola and Pinus gradually decreased with temperature extremes (Fig. 3e, g), while Picea biomass was very low and did not differ between any of the treatments (Fig. 3f).

Snow removal led to the reduced biomass of Betula (25\%), Poa (21\%) and Phleum (41\%), but not consistently for Festuca (Fig. 4a). Festuca, Poa and Phleum biomass was 47, 58 and 76\%, respectively, lower following WW without snow compared to WW with snow cover (Treatment $\times$ Snow: $P<0.05)$. Snow removal increased Picea biomass by $30 \%$ (and this effect was highest in the $\mathrm{C}$ plots
(73\%), while for Pyrola the biomass was reduced by $27 \%$, although this effect was primarily restricted to the TC and WW treatments (with 9 and 3 times less biomass following snow removal). Pinus biomass was not affected by snow removal.

Nitrogen addition led to increased biomass of birch and grasses (Fig. 4b). However, this effect disappeared for Poa in the WW treatment (Treatment $\times \mathrm{N}: F_{2,256}=4.6, P<0.05$ ). Picea biomass increased by $18 \%$ in response to $\mathrm{N}$ addition, although this effect was limited to the control plants. Pinus biomass was reduced by $39 \%$ in response to $\mathrm{N}$ addition. $P o a$ was the only species with a significant snow $\times$ nitrogen interaction $\left(\mathrm{N} \times \mathrm{S}: F_{1,256}=6.8, P<0.01\right)$ resulting in a $44 \%$ higher biomass when provided a snow cover and N. This $\mathrm{N} \times \mathrm{S}$ effect was significant for $\mathrm{C}$ and $\mathrm{WW}$, but not for $\mathrm{TC}$.

\section{Ecophysiological responses during winter}

Ecophysiological responses to winter temperature variability varied greatly between and within plant functional groups (Table 2). Festuca respiration rates more than doubled compared to TC, while Poa and Phleum showed increased respiration only following $-10{ }^{\circ} \mathrm{C}$ freezing (Fig. 5). Respiration rates of Pyrola and Empetrum were six times higher in WW compared to TC, while the strongest responses were measured following $-10{ }^{\circ} \mathrm{C}$ freezing compared to TC for Picea (5 times higher) and Vaccinium (2 times higher). Fv/ Fm of Festuca, Phleum and Vaccinium decreased (38, 26 and $34 \%$, respectively) following freezing, while Fv/Fm of 


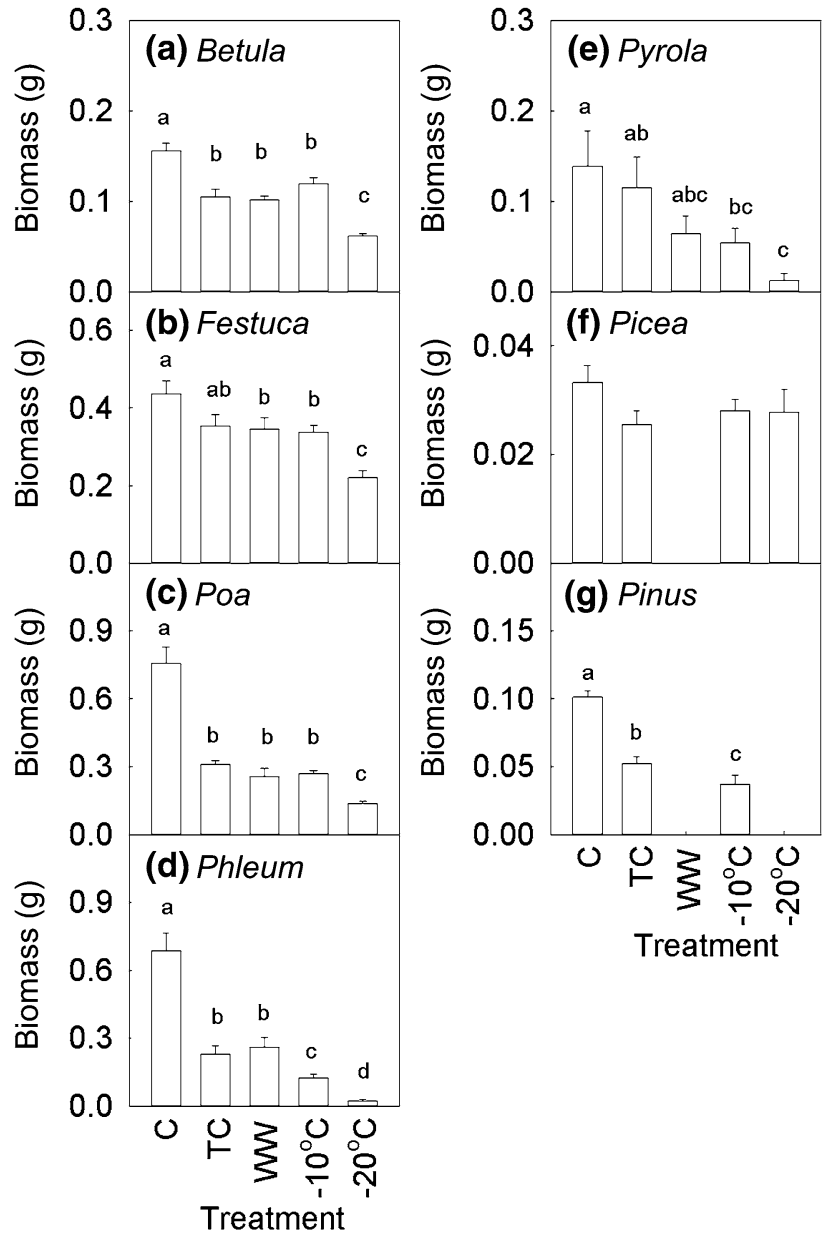

Fig. 3 Impact of extreme short winter warming events and freezing on total plant biomass. The treatments included a true control (C), a treatment control ( $\mathrm{TC}$ at $0.5^{\circ} \mathrm{C}$ ), a winter warming treatment (WW at $6{ }^{\circ} \mathrm{C}$ ) and freezing exposure to -10 and $-20^{\circ} \mathrm{C}$. Biomass values are obtained from plants that survived (see Fig. 2). Bars with different letters are significantly different (Tukey's HSD $P<0.05$ ) (see Table 1 for ANOVA results). Bars are means of $n=40-120$, as the number of plants that survived varied across species. Error bars are $1 \mathrm{SE}$

the other species was not affected (Fig. S2). Electrolyte leakage in Poa, Phleum, Pyrola and Vaccinium increased (71, 76,64 and $110 \%$, respectively) following freezing, while it was not affected in Festuca and Empetrum (Fig. S3). Picea had the highest electrolyte leakage in TC and the lowest following the $-20{ }^{\circ} \mathrm{C}$ freezing (Fig. S3). Phleum responded more strongly to $-20{ }^{\circ} \mathrm{C}$ following $0.5{ }^{\circ} \mathrm{C}(66 \%$ loss of electrolytes) than to $-20{ }^{\circ} \mathrm{C}$ following $6.0^{\circ} \mathrm{C}$ ( $44 \%$ loss). N addition reduced the electrolyte leakage of Festuca (without $\mathrm{N}$ : 44\% loss; with N 38\%). N addition increased electrolyte leakage in Poa following the $-20{ }^{\circ} \mathrm{C}$ freezing in combination with WW (94\% loss) compared to the same treatment without $\mathrm{N}(61 \%$ loss $)$.

\section{Impact on membrane fatty acid composition}

The detected fatty acid composition differed greatly between plant species, which limited direct comparisons of specific fatty acids between study species. However, changes in fatty acid composition in response to the treatments could be quantified. The PCA shows that grasses and Pyrola responded to the treatments by changing the composition of fatty acids (Table 2, Fig. S4). N addition hardly affected the plants and only the evergreen Vaccinium showed minor significant effects along PC 2 (Table 2). This change in Vaccinium was caused by a lower proportion $\left(F_{1,112}=4.3\right.$, $P=0.040$ ) of c18:1 n-9 (N added: $23 \%$; without N: $25 \%$ ).

Fatty acid composition differed between the WW and $-20{ }^{\circ} \mathrm{C}$ treatments compared to TC in Festuca and Poa, and the -10 and $-20^{\circ} \mathrm{C}$ freezing differed from TC in Phleum (Table 3). The changing composition in Festuca was driven by significant increases of c8:0 and decreases of c10:0, c12:0, c14:0, c14:1 and c18:2 n-6. Treatment differences for Poa included increases in the proportion of c11:0, c15:0, c18:0, c18:2 n-6, c22:6 n-3 and an unidentified fatty acid and a decline in c18:3 $\mathrm{n}-6$ for the $-20{ }^{\circ} \mathrm{C}$ freezing as compared to TC. Treatment differences for Phleum included decreases in c18:2 n-6, c18:3 n-3 and c22:6 n-3 in the $-20^{\circ} \mathrm{C}$ freezing compared to TC, and c16:1 n-7 decrease in WW compared to TC. For Pyrola, we observed a higher proportion of $\mathrm{c} 16: 0$ (14\%) in the $-20{ }^{\circ} \mathrm{C}$ freezing compared to TC $(11 \%)$, a lower proportion of c18:3 n- 6 in the $-10{ }^{\circ} \mathrm{C}(43 \%)$ and $-20{ }^{\circ} \mathrm{C}(46 \%)$ freezing compared to $\mathrm{TC}(55 \%)$ and a higher proportion of $\mathrm{c} 20: 2$ following the $-10{ }^{\circ} \mathrm{C}$ freezing $(29 \%)$ compared to TC (17\%).

\section{CBF expression}

Expression of the $C B F$ gene was greatly increased (30 to 100 times) following the -10 and $-20^{\circ} \mathrm{C}$ freezing for both Empetrum and Vaccinium (Fig. S5). There were no major differences between the TC and WW and no impact of $\mathrm{N}$ addition on the expression of $C B F$ (data not shown).

\section{Discussion}

This study was initiated to test if there are consistent drivers and responses between dominant functional plant types (evergreens, grasses and deciduous) in the sub-Arctic in response to extreme winter warming events against a background of increased nitrogen deposition. Evergreen dwarf shrubs and trees turned out to be more vulnerable to extreme winter warming events than grasses and a deciduous tree, confirming our first hypotheses and earlier assumptions following field simulations of extreme events and observations in nature following such events (Bokhorst et al. 2009, 
Fig. 4 Impact of snow removal (a) and nitrogen addition (b) on various sub-Arctic plant biomass and survival. Note that for the evergreen dwarf shrubs Empetrum nigrum and Vaccinium vitis-idaea there was no individual plant biomass data; hence, the $\%$ survival for the whole soil-vegetation mat is presented. Asterisks indicate significant $(P<0.05)$ differences between treatments (see Table 2 for ANOVA results). Bars are means of $n$ between 45 and 157 , as sample sizes varied across species. Error bars are $1 \mathrm{SE}$

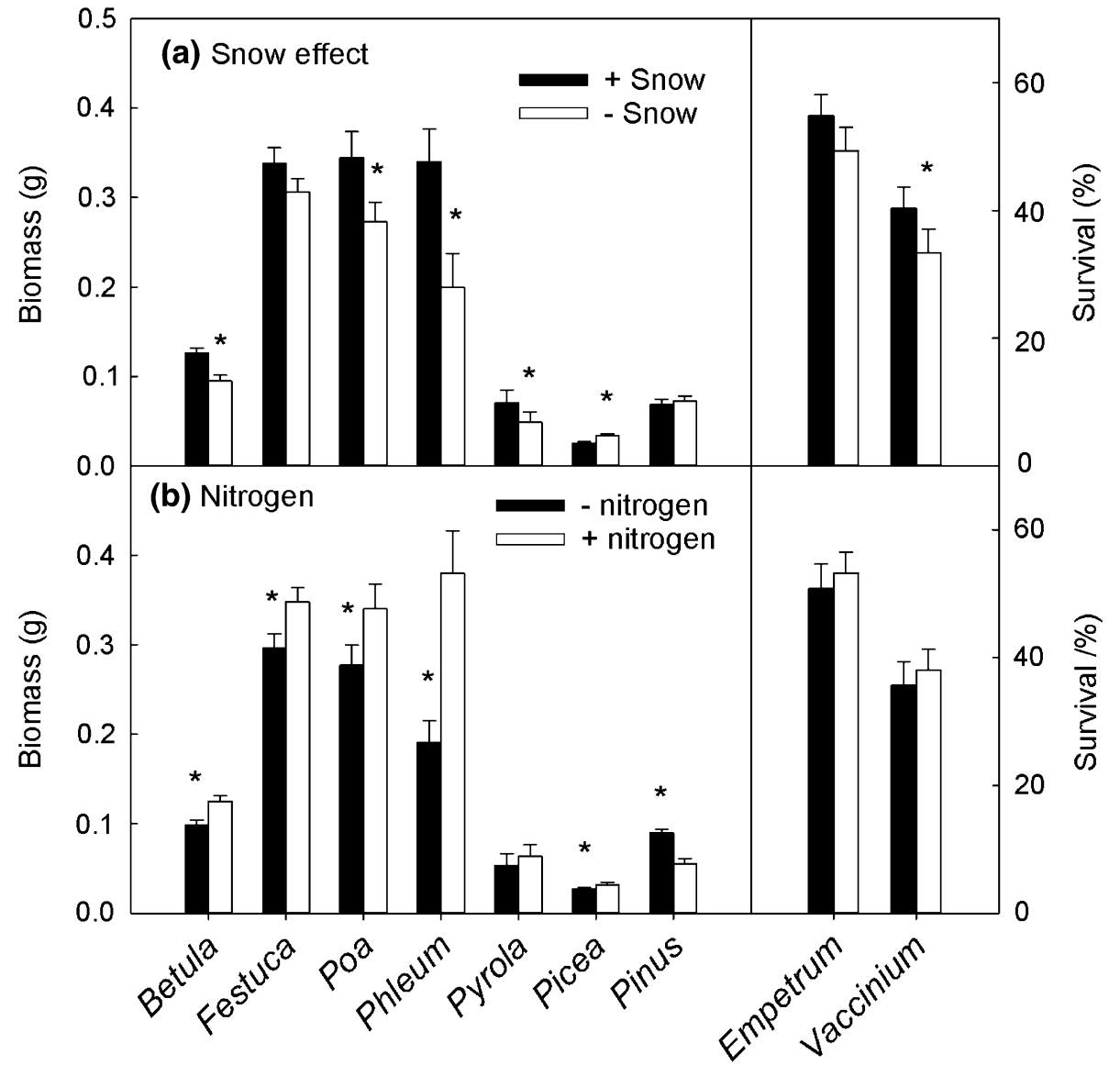

Table 1 Chi-squared and ANOVA statistics of plant survival and biomass of deciduous and evergreen species exposed to extreme winter warming simulations [Control, Treatment Control $\left(0.5^{\circ} \mathrm{C}\right)$ and Win- ter Warming], freezing $\left(-10\right.$ and $-20{ }^{\circ} \mathrm{C}$ ), snow removal (+ Snow vs. - Snow) and nitrogen additions ( 0 vs. $5 \mathrm{~kg} \mathrm{~N} \mathrm{~m}^{-2}$ year $^{-1}$ )

\begin{tabular}{|c|c|c|c|c|c|c|c|c|}
\hline & \multicolumn{4}{|c|}{ Mortality (Chi squared) } & \multicolumn{4}{|c|}{ Biomass ( $F$ values) } \\
\hline & Warming & Freezing & Nitrogen & Snow & Warming & Freezing & Nitrogen & Snow \\
\hline Betula & No mortality & & & & $11.9 * * *$ & $17.2 * * *$ & $20.5 * * *$ & $16.6 * * *$ \\
\hline Festuca & No mortality & & & & $13.5^{* * *}$ & $12.0 * * *$ & $6.2 *$ & 2.1 \\
\hline Poa & $16.3^{* * *}$ & $67.8 * * *$ & $9.0 * *$ & $9.6^{* *}$ & $155.7 * * *$ & $17.9 * * *$ & $14.6^{* * *}$ & $12.1 * * *$ \\
\hline Phleum & $39.0 * * *$ & $97.2 * * *$ & 0.1 & $12.3 * * *$ & $77.8 * * *$ & $7.4 * * *$ & $9.4 * *$ & $28.3 * * *$ \\
\hline Pyrola & 4.1 & $31.3 * * *$ & 0.1 & 0.1 & $4.2^{*}$ & 0.8 & 0.0 & $5.2 *$ \\
\hline Picea & $141.5^{* * * *}$ & $117.4 * * *$ & 0.1 & 0.1 & 3.5 & 0.2 & $4.1^{*}$ & $5.1^{*}$ \\
\hline Pinus & $122.5^{* * *}$ & $145.2 * * *$ & 2.6 & 0.1 & $\begin{array}{l}106.8^{* * *} \\
\% \text { Dead biomass }\end{array}$ & $40.3^{* * *}$ & $65.8^{* * *}$ & 0.2 \\
\hline Empetrum & & & & & $35.1 * * *$ & $53.5^{* * *}$ & 0.7 & 3.5 \\
\hline Vaccinium & & & & & $57.1 * * *$ & $39.9 * * *$ & 0.6 & $5.4^{*}$ \\
\hline
\end{tabular}

With the Chi-square analysis, we tested the following null hypothesis: 'There is no difference in the number of dead and alive plants between the treatment comparisons', and lack of significance confirms this hypothesis. Note that there was no mortality among Betula and Festuca in response to any of the treatments. Only main factors are shown for the ANOVA as there were few consistent significant interactions terms. Relevant interaction terms are mentioned in the results text. $* P<0.05$, ** $P<0.01$, *** $P<0.001$

2015). Furthermore, we wanted to test if there were consistent physiological responses behind the growth and mortality responses to such extreme events, but this was clearly not the case. However, the measured responses may have been underestimated in relation to what happens during extreme winter warming events in nature due to the partly artificial 
Table 2 ANOVA statistics ( $F$ values) of plant respiration, potential activity of photosystem II (Fv/Fm), electrolyte leakage and changes in fatty acid composition of dominant sub-Arctic plant types exposed to extreme winter warming simulations

\begin{tabular}{|c|c|c|c|c|c|c|c|}
\hline & Festuca & Poa & Phleum & Pyrola & Picea & Vaccinium & Empetrum \\
\hline \multicolumn{8}{|c|}{ Respiration rate $\left(\mu \mathrm{mol} \mathrm{CO} \mathrm{C}^{-1} \mathrm{~s}^{-1}\right)$} \\
\hline Warming treatment & $12.8 * *$ & $18.8 * * *$ & $4.8^{*}$ & 1.2 & $12.4 * *$ & $24.0 * * *$ & 0.8 \\
\hline Extreme temperature & $7.9 * * *$ & $18.3 * * *$ & $6.9 * * *$ & $35.5 * * *$ & $17.9 * * *$ & $10.4 * * *$ & $4.3 * *$ \\
\hline Nitrogen addition & 0.8 & 2.1 & 1.1 & 2.9 & 1.5 & 0.4 & 0.3 \\
\hline \multicolumn{8}{|l|}{$\mathrm{Fv} / \mathrm{Fm}$} \\
\hline Warming treatment & 0.7 & 3.3 & 3.7 & 2.4 & 2.0 & 0.9 & 1.4 \\
\hline Extreme temperature & $4.4^{* *}$ & 2.3 & $12.2 * * *$ & 2.5 & 0.6 & $4.2 * *$ & 0.5 \\
\hline Nitrogen addition & 0.5 & 0.3 & 0.6 & 0.2 & 2.0 & 0.1 & 2.3 \\
\hline \multicolumn{8}{|l|}{ Electrolyte leakage (\%) } \\
\hline Warming treatment & 0.3 & 3.3 & 0.0 & 3.2 & $21.9 * * *$ & 3.2 & 0.0 \\
\hline Extreme temperature & 2.5 & $22.3 * * *$ & $9.3 * * *$ & $5.1 * *$ & $17.4 * * *$ & $4.3 * *$ & 1.8 \\
\hline Nitrogen addition & $5.8^{*}$ & 0.3 & 2.4 & 2.5 & 0.0 & 0.4 & 0.0 \\
\hline \multicolumn{8}{|l|}{ Membrane fatty acids } \\
\hline \multicolumn{8}{|l|}{$\mathrm{PC} 1$} \\
\hline Warming treatment & 0.0 & $10.1 * *$ & $9.5 * * *$ & 0.4 & 0.5 & 3.2 & 0.2 \\
\hline Extreme temperature & $4.0 * *$ & $7.1 * * *$ & 2.5 & $3.7 *$ & 2.8 & 2.1 & 1.1 \\
\hline Nitrogen addition & 1.1 & 0.1 & 0.1 & 0.4 & 0.1 & 1.6 & 0.0 \\
\hline \multicolumn{8}{|l|}{ PC2 } \\
\hline Warming treatment & 2.7 & 1.5 & 1.7 & - & - & 1.2 & 0.3 \\
\hline Extreme temperature & 2.1 & 1.2 & 1.1 & - & - & 1.5 & 1.7 \\
\hline Nitrogen addition & 0.5 & 0.1 & 1.6 & - & - & $4.6^{*}$ & 1.0 \\
\hline
\end{tabular}

Winter warming treatments: TC: $0.5{ }^{\circ} \mathrm{C}$, WW: $6.0{ }^{\circ} \mathrm{C}$; extreme temperature treatments: $0.5,6.0,-10$ and $-20^{\circ} \mathrm{C}$; nitrogen addition treatments: 0 or $5 \mathrm{~kg} \mathrm{~N} \mathrm{~m}^{2}$. $* P<0.05$, ** $P<0.01$, *** $P<0.001$. Note that the snow removal on these variables could not be tested as the snow removal treatment took place after the warming and freezing treatments in the climate chambers nature of the experiment. This aspect was revealed by the reduced plant biomass in the treatment control (TC) compared to control (C) for some of the study species. As such, the transferral to the climate chambers already had an impact on plant growth in the following season. These responses highlight the importance of events outside the growing season for plant growth rates during summer (Bokhorst et al. 2012).

Plant respiration and Fv/Fm did not show consistent responses between or among plant growth forms to the warming events, thereby not supporting the hypothesis that winter physiological activity is a primer for mortality. Winter plant physiological activity is potentially dangerous due to the risk of cell damage and freezing mortality (Schaberg 2000; Beck et al. 2004). However, our results indicate that there was no link between increased (Festuca, Pyrola and Empetrum) or very low (Poa, Phleum, Picea and Vaccinium) physiological activity and electrolyte leakage or mortality in response to extreme winter warming events. The winter physiology of Picea was poor irrespective of winter treatments and may be a factor behind the overall low summer biomass values, although there were consistent mortality responses to WW and freezing. Changes in fatty acids coincided with reduced mortality and growth limitation, suggesting that this physiological adaptation is an important strategy linked to coping with extreme winter temperature variability. Surprisingly, these changes could still occur despite plants being active for only a few days during the middle of winter. However, there were large differences between the grass species with Poa and Phleum showing increases of some of the longer unsaturated fatty acids (c22:6 n-3 docosahexaenoic acid) as expected (Senser and Beck 1982), while showing opposite responses for linoleic acid (c18:2n-6) which is known to be associated with frost resistance in white clover (Dalmannsdóttir et al. 2001). Festuca showed increases and decreases of short saturated fatty acids in response to WW and freezing with little impact on the unsaturated fatty acids. Despite these species differences, the changes in fatty acids reported here coincided with the imposed freezing stress as also shown for other plants (Uemura and Steponkus 1999; Dalmannsdóttir et al. 2001; Strimbeck et al. 2015). Overall, these results suggest that the success of the grass species in this study may in part be due to their capability to modify the fatty acid composition of their tissues. However, other physiological aspects, such as metabolites, protein and cell wall composition, which were not measured, could have also played a role (Hughes and Dunn 1996). Other adaptive mechanisms enhancing winter survival of grasses are the meristem placement at the base of the plant, where temperature fluctuations are damped and the growth of new leaves 


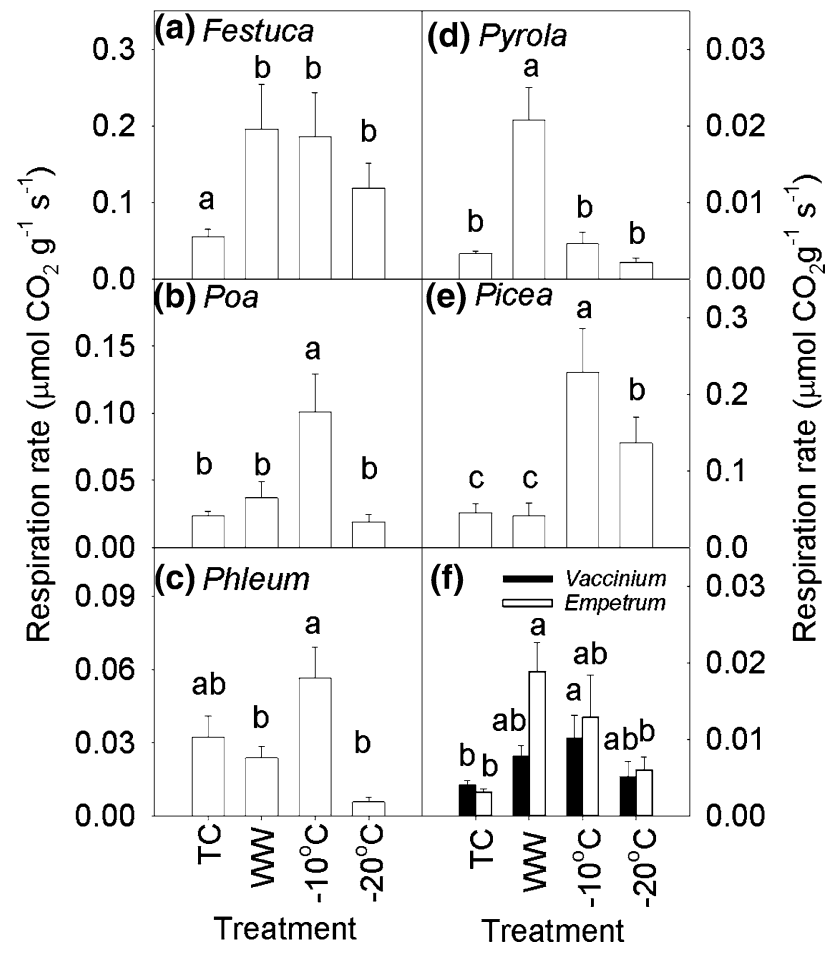

Fig. 5 Winter respiration rates of sub-Arctic plants exposed to extreme short winter warming events and freezing. The treatments included a treatment control ( $\mathrm{TC}$ at $0.5^{\circ} \mathrm{C}$ ), a winter warming treatment (WW at $6{ }^{\circ} \mathrm{C}$ ) and freezing exposure to -10 and $-20^{\circ} \mathrm{C}$. Bars with different letters are significantly different from one another (Tukey HSD $P<0.05$ ). Bars are means of $n=20$. Error bars are $1 \mathrm{SE}$

from the meristem in the next growing season (Bell 1974; Barton 2010). It is possible that other deciduous plants that have previously been shown to be resistant to field simulations and natural extreme winter warming events (Bokhorst et al. 2011, 2015) also have similar physiological adaptations and strategies.

Quantification of $C B F$ expression was unfortunately unsuccessful for grasses, and therefore we cannot make comparisons between the different plant groups in this study. $C B F$ s are DNA-binding transcriptional activator proteins, which regulate pathways affecting cold acclimatization and freezing tolerance. Higher $C B F$-protein levels in Arabidopsis thaliana increases frost tolerance and silencing of $C B F$ can lead to decreased frost tolerance (Jaglo-Ottosen et al. 1998; Oakenfull et al. 2013). The strong increases in $C B F$ expression following -10 and $-20{ }^{\circ} \mathrm{C}$ freezing in Empetrum and Vaccinium can be assumed to be associated with frost resistance (Jaglo-Ottosen et al. 1998). However, as $C B F$ expression occurred after freezing, it did not protect against damage and mortality during freezing for these dwarf shrubs. Adaptations by plants to the rapid temperature changes of extreme winter warming events may be problematic, if high $C B F$ expression is required during freezing events. These aspects need to be explored in further detail if we want to
Table 3 Differences in fatty acid proportions for three sub-Arctic grass species in response to extreme short winter warming events and freezing

\begin{tabular}{lllll}
\hline Fatty acids & Treatments & & & \\
\cline { 2 - 5 } & TC & WW & $-10{ }^{\circ} \mathrm{C}$ & $-20{ }^{\circ} \mathrm{C}$ \\
\hline Festuca & & & & \\
c8:0 & $0.12(0.01) \mathrm{a}$ & $0.24(0.03) \mathrm{b}$ & $0.20(0.04) \mathrm{ab}$ & $0.29(0.04) \mathrm{b}$ \\
c10:0 & $0.04(0.01) \mathrm{a}$ & $0.02(0) \mathrm{b}$ & $0.03(0) \mathrm{ab}$ & $0.02(0) \mathrm{b}$ \\
c12:0 & $0.03(0.01) \mathrm{a}$ & $0.01(0) \mathrm{b}$ & $0.03(0.01) \mathrm{a}$ & $0.01(0) \mathrm{b}$ \\
c14:0 & $0.04(0.01) \mathrm{a}$ & $0.02(0.01) \mathrm{b}$ & $0.04(0.01) \mathrm{a}$ & $0.01(0) \mathrm{b}$ \\
c14:1 & $0.21(0.03) \mathrm{a}$ & $0.11(0.02) \mathrm{b}$ & $0.15(0.02) \mathrm{ab}$ & $0.12(0.02) \mathrm{b}$ \\
c18:2n-6 & $0.001(0) \mathrm{a}$ & $0.00(0) \mathrm{b}$ & $0.001(0) \mathrm{a}$ & $0.00(0) \mathrm{b}$ \\
Poa & & & & \\
c11:0 & $0.00(0) \mathrm{a}$ & $0.00(0) \mathrm{ab}$ & $0.01(0) \mathrm{b}$ & $0.01(0) \mathrm{b}$ \\
c15:0 & $0.01(0) \mathrm{a}$ & $0.01(0) \mathrm{ab}$ & $0.01(0) \mathrm{ab}$ & $0.01(0) \mathrm{b}$ \\
c18:0 & $0.01(0) \mathrm{a}$ & $0.01(0) \mathrm{ab}$ & $0.02(0) \mathrm{ab}$ & $0.02(0) \mathrm{b}$ \\
c18:2n-6 & $0.02(0.01) \mathrm{a}$ & $0.03(0.01) \mathrm{ab}$ & $0.06(0.02) \mathrm{b}$ & $0.07(0.01) \mathrm{b}$ \\
c18:3n-6 & $0.17(0.01) \mathrm{a}$ & $0.13(0.01) \mathrm{ab}$ & $0.16(0.01) \mathrm{ab}$ & $0.12(0.01) \mathrm{b}$ \\
c20:n-9 & $0.38(0.03) \mathrm{a}$ & $0.32(0.03) \mathrm{ab}$ & $0.35(0.03) \mathrm{ab}$ & $0.27(0.02) \mathrm{b}$ \\
c22:6n-3 & $0.00(0) \mathrm{a}$ & $0.02(0.01) \mathrm{ab}$ & $0.03(0.01) \mathrm{ab}$ & $0.04(0.01) \mathrm{b}$ \\
Phleum & & & & \\
c16:1n-7 & $0.02(0) \mathrm{a}$ & $0.01(0) \mathrm{b}$ & $0.02(0) \mathrm{ab}$ & $0.02(0) \mathrm{ab}$ \\
c18:2n-6 & $0.16(0) \mathrm{a}$ & $0.13(0.01) \mathrm{ab}$ & $0.15(0.01) \mathrm{ab}$ & $0.13(0.01) \mathrm{b}$ \\
c18:3n-3 & $0.48(0.02) \mathrm{a}$ & $0.43(0.03) \mathrm{ab}$ & $0.35(0.03) \mathrm{bc}$ & $0.32(0.02) \mathrm{c}$ \\
c22:6n-3 & $0.03(0) \mathrm{a}$ & $0.03(0.01) \mathrm{ab}$ & $0.04(0.01) \mathrm{ab}$ & $0.05(0.01) \mathrm{b}$ \\
\hline
\end{tabular}

The treatments included a treatment control $\left(\mathrm{TC}\right.$ at $\left.0.5{ }^{\circ} \mathrm{C}\right)$, a winter warming treatment (WW at $6{ }^{\circ} \mathrm{C}$ ) and freezing exposure to -10 and $-20{ }^{\circ} \mathrm{C}$. Note that only the fatty acids with significant proportional differences between treatments are shown. Values are means of $n=20-40$ replicates as sample size varied across species and treatments. SEs are shown between brackets. Values with different letters between treatments indicate significant $(P<0.05)$ differences

identify the genetic aspects of sub-Arctic plant responses to winter temperature stress under climate change.

A third objective of this study was to identify which winter abiotic factor was responsible for the plant damage and mortality following extreme winter warming events. Freezing to $-20{ }^{\circ} \mathrm{C}$ resulted in biomass declines across most study species, but it did not consistently increase the damage following the winter warming events. Instead, some species suffered complete dieback following the winter warming treatment (Pinus and Picea), while others were more sensitive to the freezing treatments (Vaccinium and Empetrum). $P o a$ and Phleum showed increased mortality following WW with freezing. These results do not provide direct insight into the physiological mechanism, such as ice crystallization, supercooling and frost injury (Beck et al. 2004; Liu and Osborne 2008), behind the observed plant mortality and growth reductions, but can be used to predict plant community assembly when taking winter freezing and snow conditions into account. The loss of snow cover did reduce growth 
for many species, and growth reductions were greatest in plants (Festuca, Poa, Phleum and Pyrola) not receiving a new snow cover after the winter warming event. Snow cover loss exposed plants to increased temperature variability but also to winter sunlight, which eventually would lead to evaporation losses that influence winter physiological processes and cause greater stress (Heide 1993; Neuner et al. 1999; Adams et al. 2002; Starr and Oberbauer 2003; Siffel and Santrucek 2005). Although we cannot identify the specific mechanism and causes behind the observed changes in biomass following shallower snow regimes, this aspect of the winter ecology obviously plays an important role in plant growth (Bokhorst et al. 2016). Therefore, the drivers behind plant vulnerability to winter temperature extremes and changes in snow cover appears to be highly species specific, but the responses observed here can be used to predict how local plant communities may respond to future Arctic climate scenarios. As such, we can expect that evergreen plants will be negatively impacted following increased winter temperature and snow variability, while grasses, especially Poa and Festuca, and deciduous plants are better adapted to these potentially stressful conditions (Kreyling et al. 2008; Bokhorst et al. 2015).

Finally, we expected that higher $\mathrm{N}$ availability would promote plant growth, but simultaneously increased vulnerability to freezing stress due to changes in cell and physiological characteristics associated with drought and frost susceptibility (Macgillivray et al. 1995; Carroll et al. 1999; Schaberg et al. 2002). The grasses and Betula responded positively to $\mathrm{N}$ additions, while the dwarf shrubs and evergreen seedlings did not. These results most likely reflect the faster growth rate of the deciduous species over the evergreen species (Cornelissen et al. 1996; Wright et al. 2004). Multiple growing seasons with higher $\mathrm{N}$ availability may also result in increased growth of the evergreen study species (Aerts 2010). The higher $\mathrm{N}$ availability did interact with WW and freezing treatments leading to higher membrane damage and mortality of Poa. However, the majority of species did not show any response to the interaction of $\mathrm{N}$ and temperature variability. Therefore, higher $\mathrm{N}$ availability does not necessarily increase vulnerability to freezing stress (Taulavuori et al. 2014). However, the $\mathrm{N}$ loading in this experiment was chosen at a relatively low level (Phoenix et al. 2012) to simulate realistic pollution levels, and loadings beyond natural levels may induce higher vulnerability to the combination of stressors.

In conclusion, the evergreen dwarf shrubs and tree seedlings were more susceptible to extreme winter warming events than grasses and Betula. Physiological activity during the extreme winter warming event was not a precursor for growth reduction and mortality rates. Instead, plant species that changed their membrane fatty acid composition in response to the winter warming and freezing showed least growth reductions and mortality. Furthermore, the drivers (winter warming event or freezing) of growth reductions and mortality were not consistent between species and functional groups, making it hard to make predictions for large plant group responses to climate scenarios. However, this work does indicate that evergreen plants appear the most vulnerable, compared to grasses and other deciduous plants, when facing future warmer winter climate conditions.

Author contribution statement SB and JWB designed and conducted the experimental work. All authors wrote or commented on the main text and supplementary notes. LJ and KK were responsible for the $C B F$ gene analyses, and GKE and HKM were responsible for the fatty acid analyses.

Acknowledgements We would like to thank all people who provided invaluable assistance during the field and laboratory work conducted for this research: Geraldine Mabille, Trond Vidar Johnsen, Ellen Elverland, Ilona Peltoniemi, Martina Schwartzmüller, Leif Einar Støvern, Marijn Bokhorst, Marit Jørgensen, Matthias Zielke, Leidulf Lund, Kjell Nilsen, Sofi Sandström and Kristian Laustsen. This work was financed by a Grant from the Research Council of Norway (Grant no. 225006) to J.W.B. and S.B., and by financial support from the Flagship Programme "Effects of climate change on terrestrial ecosystems, landscapes, society and indigenous peoples" of FRAM-High North Research Centre for Climate and the Environment. We acknowledge Statskog SF for permission to collect vegetation mats on their property.

\section{Compliance with ethical standards}

Conflict of interest The authors declare that they have no conflict of interest.

Open Access This article is distributed under the terms of the Creative Commons Attribution 4.0 International License (http://creativecommons.org/licenses/by/4.0/), which permits unrestricted use, distribution, and reproduction in any medium, provided you give appropriate credit to the original author(s) and the source, provide a link to the Creative Commons license, and indicate if changes were made.

\section{References}

Adams WW, Demmig-Adams B, Rosenstiel TN, Brightwell AK, Ebbert V (2002) Photosynthesis and photoprotection in overwintering plants. Plant Biol 4:545-557

Aerts R (2010) Nitrogen-dependent recovery of subarctic tundra vegetation after simulation of extreme winter warming damage to Empetrum hermaphroditum. Glob Change Biol 16:1071-1081

Barton MK (2010) Twenty years on: the inner workings of the shoot apical meristem, a developmental dynamo. Dev Biol 341:95-113

Beck EH, Heim R, Hansen J (2004) Plant resistance to cold stress: mechanisms and environmental signals triggering frost hardening and dehardening. J Biosci 29:449-459

Bell KL (1974) Autumn, winter and spring phenology of some Colorado alpine plants. Am Midl Nat 91:460-464

Bokhorst S, Bjerke JW, Tømmervik H, Callaghan TV, Phoenix GK (2009) Winter warming events damage sub-Arctic vegetation: 
consistent evidence from an experimental manipulation and a natural event. J Ecol 97:1408-1415

Bokhorst S, Bjerke JW, Davey M, Taulavuori K, Taulavuori E, Laine K, Callaghan TV, Phoenix GK (2010) Impacts of extreme winter warming events on plant physiology in a sub-Arctic heath community. Physiol Plant 140:128-140

Bokhorst S, Bjerke JW, Street LE, Callaghan TV, Phoenix GK (2011) Impacts of multiple extreme winter warming events on sub-Arctic heathland: phenology, reproduction, growth, and $\mathrm{CO}_{2}$ flux responses. Glob Change Biol 17:2817-2830

Bokhorst S, Bjerke JW, Tømmervik H, Preece C, Phoenix GK (2012) Ecosystem response to climatic change: the importance of the cold season. Ambio 41:246-255

Bokhorst S, Phoenix GK, Berg MP, Callaghan TV, Kirby-Lambert C, Bjerke JW (2015) Climatic and biotic extreme events moderate long-term responses of above- and belowground sub-Arctic heathland communities to climate change. Glob Change Biol 21:4063-4075

Bokhorst S, Pedersen SH, Brucker L, Anisimov O, Bjerke JW, Brown RD, Ehrich D, Essery RLH, Heilig A, Ingvander S, Johansson C, Johansson M, Jónsdóttir IS, Inga N, Luojus K, Macelloni G, Mariash H, McLennan D, Rosqvist GN, Sato A, Savela H, Schneebeli M, Sokolov A, Sokratov SA, Terzago S, Vikhamar-Schuler D, Williamson S, Qiu Y, Callaghan TV (2016) Changing Arctic snow cover: a review of recent developments and assessment of future needs for observations, modelling, and impacts. Ambio 45:516-537

Browse J, McCourt PJ, Somerville CR (1986) Fatty acid composition of leaf lipids determined after combined digestion and fatty acid methyl ester formation from fresh tissue. Anal Biochem 152:141-145

Buchner O, Neuner G (2011) Winter frost resistance of Pinus cembra measured in situ at the alpine timberline as affected by temperature conditions. Tree Physiol 31:1217-1227

Caporn SJM, Risager M, Lee JA (1994) Effect of nitrogen supply on frost hardiness in Calluna vulgaris (L) Hull. New Phytol 128:461-468

Carroll JA, Caporn SJM, Cawley L, Read DJ, Lee JA (1999) The effect of increased deposition of atmospheric nitrogen on Calluna vulgaris in upland Britain. New Phytol 141:423-431

Choudhary S, Blaud A, Osborn AM, Press MC, Phoenix GK (2016) Nitrogen accumulation and partitioning in a High Arctic tundra ecosystem from extreme atmospheric $\mathrm{N}$ deposition events. Sci Total Environ 554-555:303-310

Cornelissen JHC, Diez PC, Hunt R (1996) Seedling growth, allocation and leaf attributes in a wide range of woody plant species and types. J Ecol 84:755-765

Cornelissen JHC, van Bodegom PM, Aerts R, Callaghan TV, van Logtestijn RSP, Alatalo J, Chapin FS, Gerdol R, Gudmundsson J, Gwynn-Jones D, Hartley AE, Hik DS, Hofgaard A, Jonsdottir IS, Karlsson S, Klein JA, Laundre J, Magnusson B, Michelsen A, Molau U, Onipchenko VG, Quested HM, Sandvik SM, Schmidt IK, Shaver GR, Solheim B, Soudzilovskaia NA, Stenstrom A, Tolvanen A, Totland O, Wada N, Welker JM, Zhao XQ (2007) Global negative vegetation feedback to climate warming responses of leaf litter decomposition rates in cold biomes. Ecol Lett 10:619-627

Dalmannsdóttir S, Helgadottir A, Gudleifsson BE (2001) Fatty acid and sugar content in white clover in relation to frost tolerance and ice-encasement tolerance. Ann Bot 88:753-759

De Deyn GB, Cornelissen JHC, Bardgett RD (2008) Plant functional traits and soil carbon sequestration in contrasting biomes. Ecol Lett 11:516-531

Forsius M, Posch M, Aherne J, Reinds GJ, Christensen J, Hole L (2010) Assessing the impacts of long-range sulfur and nitrogen deposition on Arctic and sub-Arctic ecosystems. Ambio 39:136-147
Hadley JL, Smith WK (1986) Wind effect on needles of timberline conifers-seasonal influence on mortality. Ecology 67:12-19

Hadley JL, Smith WK (1989) Wind erosion of leaf surface wax in alpine timberline conifers. Arct Alp Res 21:392-398

Heide OM (1993) Daylength and thermal time responses of budburst during dormancy release in some northern deciduous trees. Physiol Plant 88:531-540

Hughes MA, Dunn MA (1996) The molecular biology of plant acclimation to low temperature. J Exp Bot 47:291-305

Inouye DW (2000) The ecological and evolutionary significance of frost in the context of climate change. Ecol Lett 3:457-463

Jaakola L, Pirttilä AM, Halonen M, Hohtola A (2001) Isolation of high quality RNA from bilberry (Vaccinium myrtillus L.) fruit. Mol Biotechnol 19:201-203

Jaglo-Ottosen KR, Gilmour SJ, Zarka DG, Schabenberger O, Thomashow MF (1998) Arabidopsis $C B F 1$ overexpression induces $C O R$ genes and enhances freezing tolerance. Science 280:104-106

Karlsson PE, Ferm M, Tømmervik H, Hole LR, Pihl Karlsson G, Ruoho-Airola T, Aas W, Hellsten S, Akselsson C, Mikkelsen TN, Nihlgård B (2013) Biomass burning in eastern Europe during spring 2006 caused high deposition of ammonium in northern Fennoscandia. Environ Pollut 176:71-79

Kathke S, Bruelheide H (2011) Differences in frost hardiness of two Norway spruce morphotypes growing at Mt. Brocken, Germany. Flora 206:120-126

Kreyling J, Beierkuhnlein C, Pritsch K, Schloter M, Jentsch A (2008) Recurrent soil freeze-thaw cycles enhance grassland productivity. New Phytol 177:938-945

Liston GE, Hiemstra CA (2011) The changing cryosphere: pan-Arctic snow trends (1979-2009). J Clim 24:5691-5712

Liu M-Z, Osborne CP (2008) Leaf cold acclimation and freezing injury in C(3) and C(4) grasses of the Mongolian Plateau. J Exp Bot 59:4161-4170

Lund AE, Livingston WH (1999) Freezing cycles enhance winter injury in Picea rubens. Tree Physiol 19:65-69

Macgillivray CW, Grime JP, Band SR, Booth RE, Campbell B, Hendry GAF, Hillier SH, Hodgson JG, Hunt R, Jalili A, Mackey JML, Mowforth MA, Neal AM, Reader R, Rorison IH, Spencer RE, Thompson K, Thorpe PC (1995) Testing predictions of the resistance and resilience of vegetation subjected to extreme events. Funct Ecol 9:640-649

Mæhre HK, Hamre K, Elvevoll EO (2013) Nutrient evaluation of rotifers and zooplankton: feed for marine fish larvae. Aquac Nutr 19:301-311

Murray MB, Cape JN, Fowler D (1989) Quantification of frost damage in plant tissues by rates of electrolyte leakage. New Phytol 113:307-311

Neuner G, Ambach D, Aichner K (1999) Impact of snow cover on photoinhibition and winter desiccation in evergreen Rhododendron ferrugineum leaves during subalpine winter. Tree Physiol 19:725-732

Oakenfull RJ, Baxter R, Knight MR (2013) A C-repeat binding factor transcriptional activator $(C B F / D R E B 1)$ from European Bilberry (Vaccinium myrtillus) induces freezing tolerance when expressed in Arabidopsis thaliana. PLoS One 8:e54119

Ögren E (1996) Premature dehardening in Vaccinium myrtillus during a mild winter: a cause for winter dieback? Funct Ecol 10:724-732

Pagter M, Arora R (2013) Winter survival and deacclimation of perennials under warming climate: physiological perspectives. Physiol Plant 147:75-87

Phoenix GK, Emmett BA, Britton AJ, Caporn SJM, Dise NB, Helliwell R, Jones L, Leake JR, Leith ID, Sheppard LJ, Sowerby A, Pilkington MG, Rowe EC, Ashmorek MR, Power SA (2012) Impacts of atmospheric nitrogen deposition: responses of multiple plant and soil parameters across contrasting ecosystems in long-term field experiments. Glob Change Biol 18:1197-1215 
Post E, Forchhammer MC, Bret-Harte MS, Callaghan TV, Christensen TR, Elberling B, Fox AD, Gilg O, Hik DS, Høye TT, Ims RA, Jeppesen E, Klein DR, Madsen J, McGuire AD, Rysgaard S, Schindler DE, Stirling I, Tamstorf MP, Tyler NJC, van der Wal R, Welker JM, Wookey PA, Schmidt NM, Aastrup P (2009) Ecological dynamics across the arctic associated with recent climate change. Science 325:1355-1358

Power SA, Ashmore MR, Cousins DA, Sheppard LJ (1998) Effects of nitrogen addition on the stress sensitivity of Calluna vulgaris. New Phytol 138:663-673

R Core Team (2015) R: a language and environment for statistical computing. R Foundation for Statistical Computing, Vienna

Rose TM, Henikoff JG, Henikoff S (2003) CODEHOP (COnsensusDEgenerate Hybrid Oligonucleotide Primer) PCR primer design. Nucleic Acids Res 31:3763-3766

Schaberg PG (2000) Winter photosynthesis in red spruce (Picea rubens Sarg.): limitations, potential benefits, and risks. Arct Antarct Alp Res 32:375-380

Schaberg PG, Shane JB, Hawley GJ, Strimbeck GR, DeHayes DH, Cali PF, Donnelly JR (1996) Physiological changes in red spruce seedlings during a simulated winter thaw. Tree Physiol 16:567-574

Schaberg PG, DeHayes DH, Hawley GJ, Murakami PF, Strimbeck GR, McNulty SG (2002) Effects of chronic N fertilization on foliar membranes, cold tolerance, and carbon storage in montane red spruce. Can J For Res 32:1351-1359

Senser M, Beck E (1982) Frost resistance in spruce (Picea abies (L.) Karst.): V. Influence of photoperiod and temperature on the membrane lipids of the needles. Z Planzenphysiol 108:71-85

Siffel P, Santrucek J (2005) Diurnal course of photochemical activity of winter-adapted Scots pine at subzero temperatures. Photosynthetica 43:395-402

Starr G, Oberbauer SF (2003) Photosynthesis of arctic evergreens under snow: implications for tundra ecosystem carbon balance. Ecology 84:1415-1420
Steponkus PL (1984) Role of the plasma membrane in freezing injury and cold acclimation. Ann Rev Plant Physiol 35:543-584

Strimbeck GR, Schaberg PG, Dehayes DH, Shane JB, Hawley GJ (1995) Midwinter dehardening of montane red spruce during a natural thaw. Can J For Res 25:2040-2044

Strimbeck GR, Schaberg PG, Fossdal CG, Schroder WP, Kjellsen TD (2015) Extreme low temperature tolerance in woody plants. Front Plant Sci 6:15

Taulavuori K, Taulavuori E, Sheppard LJ (2014) Truths or myths, fact or fiction, setting the record straight concerning nitrogen effects on levels of frost hardiness. Environ Exp Bot 106:132-137

Thomashow MF (1999) Plant cold acclimation: freezing tolerance genes and regulatory mechanisms. Annu Rev Plant Physiol Plant Mol Biol 50:571-599

Uemura M, Steponkus PL (1999) Cold acclimation in plants: relationship between the lipid composition and the cryostability of the plasma membrane. J Plant Res 112:245-254

Uemura M, Joseph RA, Steponkus PL (1995) Cold acclimation of Arabidopsis thaliana - effect on plasma membrane lipid composition and freeze-induced lesions. Plant Physiol 109:15-30

Vikhamar-Schuler D, Isaksen K, Haugen JE, Tømmervik H, Luks B, Schuler TV, Bjerke JW (2016) Changes in winter warming events in the Nordic Arctic region. J Clim 29:6223-6244

Wright IJ, Reich PB, Westoby M, Ackerly DD, Baruch Z, Bongers F, Cavender-Bares J, Chapin T, Cornelissen JHC, Diemer M, Flexas J, Garnier E, Groom PK, Gulias J, Hikosaka K, Lamont BB, Lee T, Lee W, Lusk C, Midgley JJ, Navas M-L, Niinemets U, Oleksyn J, Osada N, Poorter H, Poot P, Prior L, Pyankov VI, Roumet C, Thomas SC, Tjoelker MG, Veneklaas EJ, Villar R (2004) The worldwide leaf economics spectrum. Nature 428:821-827 